\title{
Mirosław Szegda
}

\section{Drugi Sobór Watykański a zjednoczenie chrześcijan Wschodu i Zachodu}

Prawo Kanoniczne : kwartalnik prawno-historyczny 3/3-4, 281-310

1960

Artykuł został zdigitalizowany i opracowany do udostępnienia w internecie przez Muzeum Historii Polski w ramach prac podejmowanych na rzecz zapewnienia otwartego, powszechnego i trwałego dostępu do polskiego dorobku naukowego i kulturalnego. Artykuł jest umieszczony w kolekcji cyfrowej bazhum.muzhp.pl, gromadzącej zawartość polskich czasopism humanistycznych i społecznych.

Tekst jest udostępniony do wykorzystania w ramach dozwolonego użytku. 


\section{Ks. MIROSLAW SZEGDA}

\section{DRUGI SOBOR WATYKAÑSKI}

\section{A ZJEDNOCZENIE CHRZEŚCIJAN WSCHODU I ZACHODU}

Zyjemy w epoce uniwersalizmu, w epoce wzmożonych tendencji do zjednoczenia politycznego, ekonomicznego, kulturalnego oraz religijnego. Swiatowe organizacje (ONZ, UNESCO, MOP - Międzynarcdowa Organizacja Pracy, OMS - Swiatowa Organizacja Zdrowia, WCC - Swiatowa Rada Kościołów), międzynarodowe kongresy i zjazdy sa dobitnym wyrazem dążenia narodów do wzajemnego zbliżenia i zjednoczenia. Rozwój techniczny, który już od wielu lat realizuje jedność materialną naszej planety, przyczynil się również w wielkiej mierze do poglębienia oraz upowszechnienia chrześcijańskiej doktryny Q jedności duchowej calej Iudzkości. Toteż jeszcze nigdy nie bylo takiego nasilenia tęsknoty za zjednoczeniem ludzkości oraz zniwelowaniem dzielących ją partykularyzmów i separa!yzmów. Wydaje się, że ludzkość widzi w tym wzajemnym zjednoczeniu jakby swe ocalenie przed jakimś kataklizmem, a równocześnie poprawę wydatną swego bytu w przyszłości. Ten ruch swiatowy uwydatnil się również i w życiu Kościołów chrześcijańskich. Bo oto $w$ rozbitym i skłóconym świecie chrześcijańskim, poza Kościołem katolickim, zatacza coraz szersze kregi ruch zjednoczeniowy pod nazwa ruchu ekumenicznego'. Dziś

1 Ruch ekumeniczny zrodzil się na Zachodzie z dwóch prądów, mających za cel przywrócenie dawnej jedności między chrześcijanami. Jeden z tych prądów dążyl przez pominięcie dzielących ró nic do zjednoczenia sie w stosowaniu etyki chrzescijanskiej w życiu prywat- 
ruch ten w organizacji międzywyznaniowej, znanej pod nazwą Swiatowej Rady Kościóów, jednoczy w sobie 176 Kościołów protestanckich i prawos'awnych ${ }^{2}$. Ruch ekumeniczny budzi nadzie „e na zjednoczenie $w$ przyszlości tych chrześcijan z Kościołem katolickim, ale i obawę, aby ten ruch z czasem nie przekształcił się $w$ ruch zmierzający do interkonfesjonalizmu. Interkonfesjonslizm jest glównym niebezpieczeńtwem dla ruchu ekumenicznego, jest bowiem przekreśleniem wszelkich perspektyw tego ruchu ${ }^{3}$. Gdyz interkonfesjonalizm nie wzbogaca i nie ożywia, ale wprost przeciwnie zuboża i uśmierca wyznania religijne przez zbyt radykalne ich zniwelowanie. $S x-$ geruje on mianowicie zjednoczenie $w$ oparciu o wypośrodkowane minimum chrześcijaństwa, na przykład, na wierze w Bóstwo Chrystusa, z pominięciem Kościoła i Sakramen'ów świętych, które dzielą chrześcijan. A wiemy, niestety, iż wiara musi być integralna, nie wolno $z$ niej niczego usuwać czy lekceważyć, aby mogia być twórczą i uświęcającą. Równ:eż powszechność jakiegoś wyznania osiąga się przez pogłębienie i dopałnienie, a nie przez uproszczenie oraz sprymityzowanie. Miejmy nadzieję jednak, że Kościoły prawosławne, które odznaczają się wielkim konserwatyzmem oraz skrupulatnym przestrzega-

nym i społec-nym. Stąd nosił nazwę prądu "Źycia i czynu" (Life and Work) i wprowadzil „praktyczne chrześcijaństwo". Drugi zaś z tych prądów dążył do zjedncc.enia chrześcijan na p’aszczyźnie wspólnej wiary, na którą zgodziliby się wszyscy chrześcijanie. Drugi prąd nazywał się prąde.n "Wiary i ustroju" (Faith and Order). Pierwszy ukonstytut.wał się na konferencji międzynarıdowej $w$ Stıckholmie w r. 19ะ5, a drugi w Lozannie w r. 1927. - Por. Oriens, 1937, z. 5, 153

2 Swiatowa Rada Kościolćw (WCC - World Council of Churches) ukonstytucwała się $w$ sierpniu 1948 r. W Amsterdam:e. Naczelnym organem Rady jest Plenarne Zebranie wszystkich członków, t. zn. 176 Kcściołw należących do niej. Plenarne Zebranie zbiera się co 6 lat i ws biera Prezydium, złożone z 6 osób, w którym są reprezentowane najliczniejs:e wyznania. Plenarne Zebranie wybiera również 12 członków Komitetu Wykonawczego i lic:niejszy osobswo K:mitet Centralny, który się zbiera raz w roku. Sekretariat Generalny wraz z licznymi Wydziałami oraz Komisjami mieści się w Genewie.

3 Por. Bierdjajev N., Vselenskost i konfesionalism, in Christianskoie vozsojcdinenie, Paris 1932, 71-72. 
niem calości wiary i tradycji, nie dopuszczą do umocnienia się interkonfejjonalizmu w łonie Swialowej Rady Kościołów.

Kościół katolicki, dla którego jedność nie jest, jak w innych wyznaniach chrześcijańskich cєlem, ale realną rzeczywistością, ustosunkował się do dążeń ruchu ekumeniczne zo $\mathrm{z}$ dużym zrozumieniem i życzliwością4. Wprawdzie hierarchia Kościoła katolickiego rzadko tylko bierze udzial $w$ zjazdach ekumenicznych, natomiast często uczestniczą $w$ nich wybitni teologowie katoliccy5. Zezwala się katolikom na obcowanie, a nawet zacieśnianie więzćw z wiernymi innych wyznań chrześcijańskich, aby $w$ ten sposśb niekatolikom wyjść naprzeciw tak daleko, jak to ty'ko jest możliwe - zgcdnie $\mathrm{z}$ has'em ekumenicznym: „Przez miłość do wiary!"“ I zupełnie słusznie. Mówimy bowiem - zjednoczeniu Kościoła Chrystusowego, a Kościół to przecież my wszyscy, a więc my wszyscy mamy się przyczynić do zjadnoczenia. Zjednoczenie to nie tylko usunięcie różnic dogmatycznych, ale przezwyciężenie trudności natury psychologicznej - wzajemnej niechęci, nieufności i uprzedzenia - czyii sprawa miłości pomiędzy powaśnicnymi wyznawcami Chrystu-

4 Ojciec św. Jan XXIII $w$ encyklice ,Ad Petri Cathedram z 2.VII. 1959 (AAS, 51 (1959) 511) pisze: ,Jest dla nas pocieszającą wiadomośc, ze $w$ ostatnich czesach uwydatnil się pewien ruch wspóln th oddzielonych od Katedry św. Piotra, przychylny wierze i organizacji Kościoła katolickiego... wiemy rćwnież, iż prawie wszyscy nazywający się chrześcijanami, choć ođłączeni cd nas i rozłąceni między sobą, zorganizowali kilka razy kongresy i stworzyli specjalną organizacją, celem nawiązania łąc $n$ sści między sobą. Wraża to ich wielkie pragnienie osiągniłcia jakiejk slwiek formy jedncści... Pozwólcie, abyśmy was z serdecznym pragnieniem nazwali Braćmi i Synami. Mamy nadzieję, że do nas powrócicie i otoczymy was cpieką ojc swskich uczuć".

5 Jedna $z$ wį̨kszych konferencji odbyła się 27.III.1960 w Aleksandrii, w kolegium św. Marka $z$ udzialem przedstawicieli Kości ła katolickiego, prawosławnego i protestanckiego. $Z$ hierarchii katolickiej byli tam obecni: patriarcha aleksandryjski, Chrystophoras II, rzym-kat. wikariusz apsstolski Aleksandrii, bp Jan Kapistran Cayer, arcbp obrządku melchickiego w Syrii, Fi jtr Chami oraz inni biskupi i hierarchowie wschodnich obrządkjw katolickich, jak koptyjskiego, maronickiego, ormiańskiego i syryjskiego.

- Por. Instrukcję S. C. Officii "De motione oecumenica" z 20.XII. 1949 r. - AAS. 32 (1950), $142-147$. 
sa. Tezę tę popularyzuje obecny Ojciec św., Jan XXIII, ktöry w przemówieniu do dyrektorów Papieskiego Dziela Misyjnego, zaapelował do wszystkich katolików, aby podjęli próbę wielkiego zrozumienia wobec braci odłączonych, wzniesienia się ponad wszelkie przesady i uprzedzenia, ponad dawne sformulowania, aby tylko stworzyć sprzyjający klimat i ułatwić działanie łaski?. Kiedy indziej Ojciec św. wyraził się, że pracując nad zjednoczeniem, trzeba być przede wszystkim bardzo łagodnym i pokornym, ponadto trzeba być cierpliwym i umieć czekać przy jścia godziny Bożej. Zanim zacznie się mówić o tym, co nas dzieli, należy kłaść nacisk na to, co nas łączy. Unikać dyskusji, która może zranić cnotę miłości bliźniego. Tę nową metode $w$ pracy nad zjednoczeniem chrześcijan, propagowal jeszcze w ubiegłym stuleciu genialny filozof rosyjski, Wlodzimierz Solowiew († 1900), który glosil, że podobnie jak nienawiść zniszczyła jedność Kościola, tak miłość jest najlepszym srodkiem i najpierwszym warunkiem zjednoczenia Kościołów chrześcijańzkich. Słuszność tej metody potwierdza historia, która poucza nas, iż zjednoczenie to bardziej sprawa miłości, aniżeli dogmatów, albowiem herezje czy schizmy najczęściej powsiawaly nie tyle na tle samych różnic teologicznych, ale więcej jeszcze na tle wzajemnych uprzedzeń oraz konfliktów. Przeciez przed schizmą była jedność we wierze obu Kościolów, również i później, po schizmie, jedność dogmatyczna już nieraz istniała między Kościołem wschodnim i zachodnim, a jednak zawarte unie byly nietrwale $\mathrm{i}$ nie speinily pokładanych $\mathrm{w}$ nich nadziei. Natomiast poprzez bezpośrednie kontakty i braterska miłość pomiędzy oddzielonymi od setek lat Kościołami, można odnaleźć tak wiele wspólnego i wytworzyć tak przychylną atmosfere, iż w końcu to, co dzieli, stanie się nieistotne, bezprzedmiotowe i będzie musialo ustąpić wyższej, duchowej jedności ${ }^{9}$. Ponadto Kościół katolicki przy każdej okazji zaleca

7 VI.1960 r.

8 W jesieni 1959 r., na audiencji kanonika Kościcła anglikańskiego, Donalda Rea.

9 Metoda ojca ruchu ekumenicznego, arcbpa Nathana Soederbloma w Szwecji. 
swoim wiernym modlitwę $w$ intencji zjednoczenia chrześcijan, Bóg bowiem nie da nam jedności, jeśli Go o to nie będziemy prosili. Chrystus Pan nie tylko glosił jedność, ale modlił się również o to „Aby wszyscy jedno byli..."10.

Nic dziwnego, że w tej sytuacji sprawa jedności Kościoła Chrystusowego stała się naczelną idea nowego pontyfikatu Jana XXIII' ${ }^{11}$. W pierwszym zaraz swym przemówieniu po conclave, Ojciec św. wspomniał o palącym zagadnieniu wznowienia jedności wśród chrześcijan, a w pierwszym orędziu do kardynałów oficjalnie zapowiedział rychle zwołanie Soboru Porvszechnego, który miałby zająć się tą wlaśnie sprawą, co powtórzyl publicznie 25.I.1959 r., przemawiając $w$ bazylice $s$ w. Pawła Za Murami na temat jedności Kościoła ${ }^{12}$. Do zagadnienia tego Ojciec św. powraca prawie w każdym swoim przemón’ieniu oraz poświęcił mu trzecią część swojej pierwszej programowej encykliki „Ad Petri Cathedram”13. W encyklice tej Ojciec św. w gorących słowach zwrócił się do chrześcijan niekatolików, szczególnie do Kościolów wschodnich, z zaproszaniem do jedności, konkludując: „Nie zapraszam Was do obcego Wam, lecz do własnego, do wspólnego i ojcowskiego domu".

Apel Papieża, Jana XXIII, do zjednoczenia oraz zapowiedź rychłego zwolania Scboru Powszechnego, stały się światowa sensacją i znalazły niesłychanie silny oraz żywy oddźwięk w calym świecie chrześcijańskim. Sam patriarcha Konstantynopula, Athenagoras I, powital z goracym uznaniem apel Jana XXILI i przyrzek1 współpracę $w$ celu zbliżenia Kościoła wschodniego

\footnotetext{
10 Jan 17: Modlitwa arcykapłańska.

11 Wybrany 28.X.1958 r.

12 Myśl zwołania Soboru Powszechnego, która zrodziła się w umyśle Ojca św. zaraz po wyborze, uważa on za natchnienie i dzieło Ducha Św.

13 Encyklika datowana 29.VI.1959 r., a ogłoszona 2.VII.1959 r. (AAS 51 (1959), 497-531.
} 
z zachodnim ${ }^{14}$. A przedstawiciel tegoż patriarchy, metropolita Jakowos, na konferencji Światowej Rady Kościo'ów nie zawahał się nazwać propozycji Jana XXIII wydarzeniem, które jest owocem licznych modlitw, jakie chrześcijanie calego świata zanoszą do Boga w intencji zjednoczenia Kościołów. Przy tym zapewnił, iż Kcściół konstantynopolitański jak i inne Kościoły prawcsiawne uważają za swój obowiązek przeprowadzić rozmowy z Rzymem na temat zjednoczenia. Podobnie przedsiawiciele innych Kościołów wschodnich wyrazili swoją radość z podjętej inicjatywy oraz uznali ją za godną poparcia ${ }^{15}$. Również protestanci, anglikanie, a nawet baptyści wyrazili się $z$ wielkim uznaniem o wysilkach Ojca św., potwierdzając przy tym, iż odpowiadają one pragnieniom ,modlitwom i nadziejom chrześcijan wszystkich wyznań ${ }^{16}$. Prof. Wilkens, rzecznik Zjednoczenia Kościoła Luterańskiego w Niemczech, pełen optymizmu, przewidywał, iż Sobór Powszechny zapoczątkuje nowy okres w stosunkach pomiędzy Światową Radą Kościołów a Kościołem katolickim, jak również proponował, aby sam Sobór Powszechny poprzedzić rozmowami przedstawicieli Kościola katolickiego oraz Kościołów prawoslawnych i protestanckich. Przewidywania te zdają się już urzeczywistniać. Utworzono bowiem „Międzynarodową Konferencję Katolicką dla Spraw Ekume-

14 Patriarcha Athenagoras I. znany jest $\mathrm{z}$ przychylnego stosunku do Kościoła katolickiego. On to 26.II.1950 r. oglosił encyklike, w której wezwał odłączone Kościoly do bliższych kontaktów ze Stolicą Apostclską, gdyż tylko przez Stclicę Apostolską mogą należeć do Kościoła powszechnego. - Por. Totzke I., Das ökumenische Patriarchat von Konstantinopel, in Una Sancta 1959, H. 3, 206.

15 Por. wypowiedź arcbp. Tymzteusza, zastọpy metrop. prawosł. w Polsce w Tyg. Powsz. z 27.III.1960 pt. „W obliczu Scboru Powszechneg $)^{\prime \prime}$.

16 Szwedzki protestancki bp. Bogiertz stwierdził, iż inicjatywa Jana XXIIII może stać się milowym kamieniem $w$ historii Kościoła. Anglikański arcbp. Kapstadtu pochwalił wysiłki Ojca św., gdyż jego zdaniem wszystko, co może się przyczynić do zjednoczenia pod-ielonych chrześcijan, zasługuje ze wszech mi $=r$ na poparcie, Przewodniczący Konferencji Baptystów Ameryki Eacińskiej przyznal, iz wszyscy chrześcijanie podzielają troskę Papieża o zjednoczenie Kiścicłów. Por Osservatore Romano z 2.II.19i9. 
nicznych", której zadaniem jest kon'aktowanie się ze Swiatową Radą Kościolów oraz przedstawicielami ruchu elumenicznego. Natomiast Swiatowa Rada Kościolów celem przygotowania się do zapowiedzianego Soboru, wyloniła Komisje dla sprecyzowania swego stanowiska względem Soboru. Nale ¿̇y jednak tu nadmienić, iz niezwykle zainterezowanie Soborem Powszechnym. ze strony chrześcijańskich wyznań pozakatolickich, zostało po części ostudzone oświadczeniami Sekretarza Stanu, Kardynała D. Tardiniego ${ }^{17}$, oraz innych miarodajnych csobistości. Według tych oświadczeń zapowiedziany Sobór odbędzie się w r. 1962 lub póżniej w Rzymie jako II-ģi Wałykański, ponieważ jednaks Sobór ten będzie wewnżtrzną sprawą Kościola katolickiego, gdyż zajmie się zagadnieniami doktrynalnymi oraz modernizacją Kodeksu Prawa Kanonicznego, diatego też przedstawi-ciele Kościołów niekatolickich nie będą mogli wziąć $w$ nim aktywnego udziału, a jedynie będą mogli uczestniczyć w charakterze obserwatorów. Natomiast pierwsza zapowiedź Soboru przez Papieża Jana XXIII wywołała $u$ dys.̃ydentćw wrażenie formalnego zaproszenia do wzięcia udziału $w$ naradach Soboru na temat zjednoczenia chrześcijan. Komentatorzy bowiem przeoczyli inne ustępy przemówienia Ojca św., w których wyraźnie zaznaczył, iż przyszły Sobór zajmie się całokształtem nauki katolickiej, życia chrześcijańskiego oraz wewnętrzną odnową Kościoła, a zasugerowali jakoby unia miała być głównym zadaniem Soboru. Stąd też wyniklo nieporozumienie, a nawet rozgoryczenie i rozczarowanie wśród odiączonych baaci18. Dziś mamy już autentyczne wyjaśnienia $w$ tej sprawie ze strony samego Ojca św. I tak jeszcze na początku sierpnia 1959 roku w przemówieniu do kierowników włoskiej Akcji Katolickiej, Ojciec św. oświadczyl, iż celem Soboru będzie reforma rodziny katolickiej, cdnowa życia katolickiego i dyscypliny kościelnej, aby w ten sposób Kościół katolicki mógł się stać atrakcyjnym i pociągnął do siebie również niekatolików. Czyli że chociaż

17. Konferencje prasowe $z$ dnia $30 . x .1959$ i 24.I.1969.

18 Pius XII w encyklice „Summi Pontificatus” (20.X.19:9) ữył po raz pierwszy oficjalnie określenia „odłączeni bracia”, zamiast schizmatycy czy heretycy. 
przyszly Sobór będzie wewnętrzną sprawą Kościoła katolickiego, to jednak przez ten Sobór winna się zaktualizować sprawa zjednoczenia: „Wtedy przedstawimy Kościół - powiedział $\mathrm{Pa-}$ pież - w całej jego chwale, ,bez plamy i bez zmarszezki" i powiemy tym wszystkim, którzy się od nas odkączyli, prawosławnym, protestantom itp.: „Chodźcie, Bracia, i patrzcie! Oto Kościól Chrystusowy! Usiłowaliśmy zawsze być wiernymi Chrystusowi, prosząc Go o łaskę, by Jego Kościół pozostal zawsze takim, jakim On go pragnął mieć. Przyjdźcie, przyjdźcie! Oto otwarta jest droga do spotkania, otwarta do powrotu! Przyjdźcie zająć znowu miejsce, które dla wielu z Was jest miejscem Waszych Ojców"19. Podobnie w r. 1960 podczas wypoczynku w Castel Gandolfo, na jednej z audiencji Ojciec św. po poinformowaniu pielgrzymów o przygotowaniach do Soboru, znowu podkreślił, że zadaniem Soboru będzie ogólna odnowa Kościoła, sprecyzowanie nauki i dostosowanie przepisów kościelnych do wymagań czasu, jak również rozwój w dziedzinie moralności, aby w ten sposób zachęcić odłączonych braci do powrotu do Kościola katolickiego, jako do wspólnego domu. Oto końcowe słowa: „My wiemy, że Domem jest apostolski-rzymski Kościól. Ten apostolski Kościół otworzy swoje bramy i powie: „Żyjmy w pokoju i w dążeniu do Pana - jeśli chcecie przyjść ze świadomością szczerego braterstwa"20. Papież Jan XXIII przez 20 lat przebywał na Wschodzie"21, zbyt dobrze więc zna Kościół prawosławny, aby mógł się łudzić możliwością rychlego zjednoczenia, dlatego tė chyba nie śpieszy się $z$ formalnym zaproszeniem do unii. Zreszta, formalne zaproszenie do unii jest dziś istotnie jeszcze nierealne, bo chociaź przezwyciężono w dużym stopniu już przeszkody natury psychologicznej w stosunku do chrześcijańskich wyznań pozakatolickich, to jednak nadal istnieją zbyt duże różnice doktrynalne. Mimo to Ojeiec św. celem wzajemnego zbliżenia oraz

\footnotetext{
19 Osservatore Romano $\mathrm{z}$ dnia 10.VIII.1959 $\mathrm{r}$.

$20 \mathrm{Na}$ audiencji w Castel Gandolfo dnia 11.IX.1960 r.

21 Od marca 1925 r. przez 10 lat by 1 Wizytatorem Apsstolskim w Bułgarii. Natomiast od r. 1935 do grudnia 1944 był Wikariuszem Apostolskim w Turcji oraz Delegatem Apostolskim w Grecji.
} 
poznania się zaprasza wszystkich odlączonych braci, aby na razie chociaż $w$ charakterze obserwatorów wzig̨li udzial w zapowiedzianym Soborze Powszechnym. I jedynie $\mathrm{w}$ tym sensie należy rozumieć zaproszenie zawarte $\mathrm{w}$ zapowiedzi zwolania Soboru w encyklice "Ad Petri Cathedram”, jak również w innych publicznych enuncjacjach. Zresztą, na audiencji dnia 26 lipea $1260 \mathrm{r}$. Ojciec św. najwyraźniej zakomunikował zebranym, ze: „Na zbliżający się Sobór Powszechny bə̨dą zaproszeni przedstawiciele kościołów chrześcijańskich, niezłączonych ze Stolicą Apostolską, aby mogli śledzić prace Soboru". Również, kiedy w pierwszych dniach września 1960 r. ogłaszał Ojciec św. skład Sekretariatu dla Sprawy Jedności Chrześcijan, przypomnial - potrzebie zaproszenia chrześcijan niekatolików: „Aby i oni również mogli śledzić prace Soboru i łatwiej mogli odnaleźć drogę do tej jedności, o która Jezus Chrystus zanosił do Ojca Niebieskiego tak gorącą modlitwę"22.

Chociaż odłączeni chrześcijanie mają być zaproszeni na Sobór jedynie w charakterze obserwatorów, to jednak wielu teologów na Zachođ̉zie przewiduje, iż ci zaproszeni chrześcijanie będą mogli wziąc udział w dyskusji nad pewnymi określonymi zagadnieniami. Przypuszczenie to zreszta jak gdyby znalazło potwierdzenie $w$ przemówieniu Ojca św. na jednej z niedzielnych audiencji w Castel Gandolfo, latem 1960 roku. Ojciec św. powiedział wtedy: "Odłączeni chrześcijanie mogaz wziąć udział w Soborze. Jeżeli zaś wezmą udzial w Soborze, będzie to odpowiednia okazja dla przedyskutowania z nimi warunków ich ostatecznego powrotu..." W ogóle zdaje się, iz sprawa zaproszenia cdłączonych chrześcijan na II-gi Sobór Watykański jest dotąd otwarta i nie można przewidziec w jakiej formie oraz w jakim charakterze bąda oni zaproszeni. Do powzięcia takiego wniosku skłaniaja nas choćby takie fakty, iż na I-szy Sobór Watykański byli formalnie zaproszeni prawosławni jak i protestanci, chociaż klimat był daleko bardziej niesprzyjający; następnie wybitni teologowie chrześcijańskich wyznań niekatolickich żądaja formalnego zaproszenia $z$ dopuszczeniem do obrad

22 Por. Przewodnik Katolicki, Poznań, nr. 28, z 10.IX.1960.

Prawo Kanoniczne - 19 
w sprawach spornych ${ }^{23}$, a Sekretarz Stanu, Kard. Tardini na konferencji prasowej 30.X.1959 r. wyraźnie zaznaczyl, że "delikatna ta sprawa jest przedmiotem troskliwych badań"24. Mimo wizystko jedno jest pewne, mianowicie, iż Papież Jan XXIII ożywil umysly, wzbudzil zainteresowania zjednıczeniem chrześcijan oraz przygotowal do takiego dia'ogu nad tym problemem, jaki do niedawna wydawał się niemożliwy.

Doda jyy, iż zwołanie Soboru Powszechnego przez Papieża Jana XXIII obalilo złośliwe zarzuty akatolików, jakoby sobory w Kościele katolickim byì narzucane papieżowi wbrew jezo woli, a od ogłoszenia dogmatu nieomylności papieża, nie będą w ogóle zwoływane jako zbyieczne i niepotrzebne.

Są sprawy wiecznie żywe i aktualne, które mimo upływu czasu nie idą $w$ zapomnienie. I chociaż sprawy takie wydają się nie do zrealizowania, albowiem wszystkie próby podjęte zawodzą, to jednak ludzie poszukują wciąż nowych dróg i nowych sposobów, aby tylko zamierzony cel osiągnąć. Do takich wlaśnie wiecznie żywych, niçdy nie przedawniających się problemów, należy sprawa zjednoczenia Kościoła wschodniego z zachodnim. I słusznie przypisuje się tak wieikie znaczenie temu problemowi - zjednoczenie bowiem Kościoła wschodniego $z$ zachodnim, wydaje się być pierwszym etapєm na drodze do zjednoczenia wszystkich chrześcijan w przyszłości oraz zapoczątkowaniem wszechjedności chrześcijaństwa. Kościól katolicki nie rezygnuje $z$ powrotu Kościołów protestanckich do jedności. $Z$ zadowoleniem i nadzieją śledzi jakby „rekatolizację" protestantyzmu w naszych czasach, objawiającą się wprowadzeniem kultu Matki. Bożej, w zbliżeniu w sprawach eucha-

23 Florovskij G., Das bevorstehende Konzil der römischen Kirche, in Una Sancta 1959, Heft 3, 175.

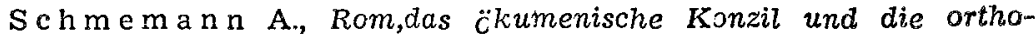
doxe Kirche, in Una Sancta 1959, Heft 4,:286.

Binder K., Die byzantinische Kirche und die Frage ihrer Union mit Rom, in Der Seelsorger 1959, Heft 1, 21.

24 Osservatore Romano z 1.XI.1959. 
rystycznych, w uznaniu tradycji oraz w przyznawaniu sukcesji apostolskiejc5. Ale jednocześnie Kościół katolicki dobrze to rozumie, iż przy dzisiejszej doktrynie oraz organizacji Kościołów protestanckich, unia $z$ protestantami jest na razie wprost nie do pomyślenia. Trzebaby, aby protestanci wyrzekli się swych wierzeń, swego Kościoła, no i tej religijnej swoboty, iż każdy wierzy wedlug sweg o wlasnego rozumienia Pisma św. - a to jest zbyt daleka droga, musi więc byc przebyta etapami. Możliwe, iż tym pierwszym ftapem jest to dość powszechne wśród protestantów zainteresowanie Kościołem katolickim i jego doktryną, silne tendencje do organizowania wzajemnej współpracy, opartej na tolerancji oraz braterskiej milości, te spon:aniczne kontakty i zebrania dyskusyjne, jak również nader przyjazne stosunki pomiędzy hierarchią obu wyznań $^{26}$. Co podobno skłania Stolicę Apostolską do zamiaru utworzenia przy Kongregacji Soborowej specjalnej Komisji dla spraw wyznania protestanckiego, z której w późniejszym terminie może się wyłonić samodzielna Kongregacja Ekumeniczna.

Nic więc dziwnego, że Stolica Apostolska przede wszystkim liczy na Wschód. Można było to łatwo dostrzec $w$ oficjalnych wypowiedziach $\mathrm{w}$ związku z zapowiedzianym Soborem Powszechnym. Nawet wypowiedzi Ojca św. wskazywały niedwuznacznie, iż głównym celem starań Stolicy Apostolskiej w sprawie zjednoczenia chrześcijan, jest chęć pogodzenia się $z$ oddzielonymi Kościołami wschodnimi27. Na przykład na publicz-

25 Pastar Lachmann w Westfali zcstał złożony $z$ urzędu, gdy ź w świężo napisanej książce chwalił Kościól katolicki. Między innymi postawił tezę, że albo jest się katolikiem, albı nie jest się chrześcijaninem w cgóle. - W Anglii zawieszono $w$ urzędowaniu pastora, który nie tylko odprawiał nabożeństwa maryjne, ale również uroczyście obchadził Wniebəwzięcie Matki Bożej.

26 Glośna wizyta prymasa Fishera u Papieża Jana XXIII dnia 1.XII.1960 r. Prymas Fisher po wizycie erygcwał w swym urzędzie prymasowskim Kom ́rkę dla kontaktów ze Stolicą Apsstolską w sprawie przyszłego Soboru.

27 Patrz korespondencja Paula Hofmanna z Rzymu w New York Times, wg. Tyg. Powsz. z 12.IV.1959. 
i

nej audiencji 21. VI. 1959 r. Ojciec św., przemawiając do 15-to. tysięcznej rzeszy pątników, zakomunikował, iż na zapowiedzianym Soborze zwróci się przede wszystkim do wschodnich chrześcian, aby powrócili do jedności. I jest to jedynie shuszne podejście, gdyż chrześcijanie wschodni pod względem dogmatycznym, hierarchicznym oraz dyscyplinarnym stoją najbliżej Kościola katolickiego. Kościół prawosławny zachował ciąglość święceń apostolskich przez kolejne nakładanie rąk, stąd posiada ważne Sakramenty św., uznaje uchwaly siedmiu pierwszych Soborów Powszechnych, co niezmiernie ułatwia zjednoczenie z Kościołem katolickim. Ponad to teologowie katoliccy sa zdania, iż dziś nastroje po obu stronach są bardziej dla idei zjednoczenia sprzyjające, niż kiedykolwiek przedtem ${ }^{28}$. Zresztą można się o tym przekonać z przychylnej reakcji Kościołów wschodnich na apel Papieża Jana XXIII do zjednoczenia chrześcijan oraz na zapowiedż zwolania Soboru, co przedstawiono powyżej. Dziś sytuacja w tym względzie przedstawia się o wiele bardziej obiecująco niż jeszcze sto lat temu. Bo oto, gdy Pius IX przed I. Soborem Watykańskim (8. IX. 1868) zwrócił się $z$ zaproszeniem do patriarchów i biskupów wschodnich, aby przystąpili do wspólpracy nad przywróceniem jedności kościelnej, podobnie jak to uczynili ich przodkowie $w$ Lyonie oraz. we Florencji, to jeanak zaproszenie zostało $z$ szyderstwem odrzucone, mimo, iż niektórzy biskupi wschodni byli zdecydowani wziąc udział w Soborze. Również, gdy później Leon XIII wezwal patriarchów wschodnich do wspólnych narad nad przywróceniem jedności, doczekal się tylko nieuprzejmej odpowiedzi z Konstantynopola ${ }^{29}$. Dziś natomiast ten sam Konstantynopol wyraża swą radość z powodu apelu do jedności, skierowanego przez Jana XXIII do Wschodu.

Do zmiany klimatu na Wschodzie przyczynił się obecny patriarcha Konstantynopola, Athenagoras I. Liczy on 74 lata,

28 Binder K., Die byzantinische Kirche..., đ. c., 20-21.

29 Pewien metropolita Synodu Patriarszego w Konstantynopolu mial się wyrazić wówczas wprost: „Wiemy przecie, że nie ma różnic we wie-rze, ale nie chcemy, aby tamci nami rządzili". Por. L e t t J., Soborowe reminiscencje, in Sodalis Marianus, Londyn 1959, $\mathrm{nr} 3,17$. 
jest mnichem $z$ góry Athos, przez diugie lata byl duszpasterzem, a następnie metropolitą grecko-prawosławnej Cerkwi w Ameryce Pólnocnej. Na patriarchę Konstantynopola zostal wybrany na synodzie w r. 1948, od 500 lat pierwszy raz jednoglośnie, następnie zatwierdzony na to stanowisko bez jakichkolwiek zastrzeżeń przez władze greckie jak i tureckie. Zna osobiście Papieża Jana XXIII z czasów misji dyplomatycznej obecnego Ojca św. na Bliskim Wschodzie ${ }^{30}$. Jak to wynika $z$ pism zagranicznych, Athenagoras I pracuje niezmordowanie nad zbìżeniem Kościoła wschodniego do Rzymu. Oto jesienia 1959 roku odwiedzil osobiście patriarchów Aleksandrii, Antiochii i Jerozolimy, planował podróż do Moskwy, celem spotkania się tam z patriarchą Aleksym ${ }^{31}$, a głównym przedmio :em jego rozmów był problem zjednoczenia Kościoła wschodniego z zachodnim. Patriarcha nosi siez z zamiarem zwołania na wyspie Rodos wszechprawoslawnego zjazdu, jakby soboru, który rozpatrzyłby możliwości zjednoczenia oraz zająlby oficjalne stanowisko względem zapowiedzianego II Soboru Watykańskiego ${ }^{32}$. Należy sądzić, iż patriarcha Athenagoras I zrozumiał szkkodliwwość rozbicia chrześcijaństwa i działa w dcbrej intencji. Co dość wyraźnie odzwierciadla się $w$ jego wypowiedziach na temat zjednoczenia. Oto w wywiadzie udzielonym korespondentowi rzymskiego dziennika "Il Popolo" powiedzial: „Dziś ważne jest przede wszystkim to, byśmy zrozumieli, iż jesteśmy braćmi: mamy bowiem to samo kapłaństwo i te same Sakramenty, czcimy tego samego Boga, a za wspomożeniem Matki Bożej znajdziemy się kiedyś w tym samym raju. Reszta to juź sprawa teologów, którzy powinni wyjaśniać trudne zagadnienia. A nie muszą to być trudności nie do pokonania, skoro udalo się je usunąć we Florencji w r. 1439. Wobec postępu techniki caly świat dziś dąży do jedności. Czyż dopuszczalne jest, by jedy-

30 Por. Binder K., Die byzantiniscine Kirche..., d. c., 20.

31 Dotąd jednak Athenagoras I z niewiadcmych przyc $y$ yn nie odby zapowiedzianej podróży. Natomiast 25.XI.1960 r. patriarcha Aleksy odleciał na Bliski Wschód, gdzie spędzil kilka tygodni.

23 Cerkovnij Vestnik, Warszawa 1960, nr 1-2, 8.

Konferencja ogólno-prawosławna na Rcdosie 24.IX.1961 r. 
nie chrześcijanie wyróżniali się w nim swymi sporami? Moga stracić his'oryczną okazję nadania chrześcijańskiego charakteru tej jedności świata, która w przeciwnym wypadku dokona się bez nich i przeciwko nim". Wielką przeszkodą jednak na drodze do zjednoczenia jest to, iż wschodni Kościól odlączony jest rozbity na kilkanaście samodzielnych patriarchatów oraz Kościołów narodowych, nie posiadających ani wspólnego kierownictwa, ani wspólnej linii działania ${ }^{33}$. Niektóre z tych Kościolów autonomicznych calą swą gorliwość wkladają $\mathrm{w}$ walkę $\mathrm{z}$ innymi Kościołami tego samego wyznania o poszerzenie etnıgraficznych granic języka, obrządku i jurysdykcji. I te narodoworeligijne konflikty mnożą się i zaostrzają, osłabiając w ten sposób jeszcze bardziej rozbity Kościół wschodni ${ }^{34}$.

Kiedy zaś choćby pobieżnie przyjrzymy się odlączonemu od Rzymu Wschodowi, to zrozumiemy, iż dziś nie Konstantynopoìi ${ }^{£ 5}$, nie Antiochię lub Aleksandrię należy uważać za decydujący czynnik w kwestii zjednoczenia Kościoła wschodniego z Rzymem. Gdyż między samodziel nymi Kościołami prawosławnymi przcdują Kościoly słowiańskie, ściślej mówiąc Cerkiew prawosławna w Związku Radzieckim ,która pomimo swych niedomagań, nie tylko liczbą swych wyznawców, ale również wiedzą teologiczną oraz wplywami na inne Kościoły prawosławne

33 Ogólem istnieje $14 \mathrm{Kcściolów} \mathrm{autokefalicznych:} \mathrm{1)} \mathrm{Konstantyno-}$ pol - patriarcha Athenagoras I, 2) Aleksandria - patr. Christophoros, 3) Damaszek - patr. Theod:sios, 4) Jerozolina - patr. Benedykt, 5) Moskwa - patr. Aleksy, 6) Ateny - arcbp. Theoklitos, 7) Nikızja arcbp. Makarios, 8) Tyflis - metrop. Melchisedech III, 9) Bukareszt patr. Justynian, 10) Belgrad - patr. Germanos, 11) Sofia patr. Cyryl, 12) Tirana - arcbp. Paisius, 13) Warszawa - meirop. Tymoteusz, 14) Praga - metrop. Jan.

34 Kartašev A., Na putiach k'vselenskomu soboru, Paris 1932, $12-19$.

35 Chociaż patriarcha Konstantynopola tradycyjnie zajmuje pierwsze miejsce wśród innych patriarchów prawsslawnych oraz nosi miano powsiechnego patriarchy.

36 Por. De Vries W, Das Problem der Wiedervereinigung des getrennten Ostens, in Stimmen der Zeit, 1960, Hefi 2, 8. 
przewodzi odłączonemu od Rzymu Wschodowi ${ }^{36}$. Niestaty, Kościół prawosławny w Związku Radzieckim, podobnie jak i dawniej za caratu, chociaż modli się w każdej Mszy św. „ం zjednoczenie świętych Bożych Kościolów”, to jednak dla samego zjednoczenia nigdy nic nie uczynił - ani nie wysunąl żadnej inicjatywy $\mathrm{w}$ tym kierunku, ani nie przyją życzliwie podobnych propozycji Zachodu ${ }^{37}$. Lud rosyjski jest źle nastawiony do wszystkiego, co katolickie, katolików uważa prawie za heretyków i odnosi się do nich $z$ niechęcią:8. Ale i tu w ostatnich ezterdziestu latach nastąpila wyraźna poprawa. Przede wszystkim odłączenie Kościoła od państwa przerwało to ciągle podsycanie nienawiści i nieufności rządów carskich (car był glową Kościoła) przeciwło Kcściołowi katolick:emu. Car jako najwyższy zwlierzchnik Kościoła, pragnąl zatrzymać w swym ręku calkowitą władzę nad Kościołem, dlatego starał się izolować Kościół od Zachodu. Wreszcie pośród prawosławnych z końca XIX i początku XX wieku byli tacy, jak Wlodzimierz Solowiew, Piotr Czadajew, prof. Suszkow, prof. Swietłow oraz prof. Bierdiajew, którzy $w$ swych pismach wyjaśnili, iż Zachód nie jest heretycki, że wiłaściwie nie ma istotnych różnic dogmatycznych z Zachodem, że wschodnie Kościoly winny zjedno-

K a rtaš e v A., Na putiach..., d. c., $31-33$.

37 Jedynie car Pawel I (†1801) według dokumentów znalezionych $\forall$ archiwach Neapolu mial priygotowywać unię Rosji z Rzymem. Pawel I jeszcze jako w. książe zwiedzal Europą, był równiė na audiencji u Piusa VI, a widząc rozbicie i upadek prawosławia w przeciwienstwie do Kościoła katclickiego, zapragnął więc zjednoczenia z Rzymem. W tym celu już jako car 5.XI.1800 r. przyjął na poufnej audiencji posła Neapolu, Serra Caprislę, i zwierzył mu się, iz uznaje papieża i w duchu jest katclikiem, przy tym wręczył posłowi list do papieża z prośbz o pcśrednictwo. Poseł 20.I.1801 r. przybyl z listem do Neapolu, aby stąd udać się do Rzymu. Nie ma pewn-ści czy car Pawel I otrzymal odpowiedź od papieża, gdyż 11.III.1801 r. zginął z ręki zamachowca.

38 Wystarczy przyp zmnieć, ij w Rosji samo tylko poprawienie ksiąg liturgicznych przez patriarchę Nikona (†1681) doprowadziło do odszczepieństwa starowierców. 
czyć się z Rzymem, gdyż prawda stoi wyżej sympatii czy antypatii ${ }^{39}$.

„Aby byli jedno, jako i my jedno jesteśmy"41 - tymi słowy modlil się Chrystus Pan przed swoją Męką o jedność między chrześcijanami. A jednocześnie pouczał i wskazywal, iz jedność ta ma być tak ścisła, jaka zachodzi pomiędzy Osobami Trójcy Przenajświętszej. W inych słowach wyjaśnil Chrystus Pan dlaczego i na co potrzebna jest tak ścisła jednośé: „Aby ¿ oni byli jedno w nas, aby świat uwierzył, żeś Ty mnio posłał"41. A więc ta jedność potrzebna jest dla wewnętrznego uświęcenia chrześcijan, gdyż prowadzi ona do zjednoczenia z Bogiem, a równocześnie potrzebna dla zewnętrznego poszerzenia wiary Chrystusowej, ona bowiem podbija świat dla Chrystusa. Nic tedy dziwnego, iż teologowie modlitwę Chrystusa Pana o jedność, nazywają testamentem Chrystusowym. $\mathrm{Z}$ powyższeg:o wynika, iż chrześcijanin, który odnosi się obojŁ̨tnie do sprawy zjednoczenia chrześcijan, nie ma $w$ sobie prawdziwego ducha Chrystusowego ${ }^{42}$. Wydaje się, iz prawosławni nie zdaja sobie sprawy czym jest $w$ istocie schizma. Dobrze więc bykoby, gdyby zapoznali się $z$ nauką św. Jana Chryzostoma i uświadomili sobie jakim wielkim zlem jest właśnie schizma, w której już cd tak dawna trwają. Sw. Chryzostom bowiem potępil schizmę podobnie jak herezję, a nawet

39 Por. Slipyj J., Unijni zmahannja $v$ ostannim pivstolittju, in Pamiętnik VI. Pińskiej Konferencji kaplańskiej $w$ sprawie unji koscielnej, Pinsk 1939, 129.

Kartašev A., $N a$ putjach..., d. c., $28 \mathrm{nn}$.

40 Jan $27,22$.

41 Tamże 27, 21.

42 Pius XI wyraził się na jednej z audiencji do ks. bpa Przeździcckiego: „Kto występuje przeciwko unii, ten nie jest prawdziwym 'katolikiem". 
pod pewnym względem surowiej43. Tłumaczył oraz wyjaśniał: „Że nic tak nie obraża Boga, jak podzial Jego Kościoła. Nawet krew męczeńska nie jest $\mathrm{w}$ stanie zmyć grzechu schizmy. Męczennik bowiem przelewa krew jedynie dla chwały Chrystusowej, Chrystus zaś duszę swoją oddal za Kościól. Kto tedy niszczy tak drogie dzieło Chrystusa, nie może zostać męczernikiem, nie jest $w$ stanie nawet krwią swoją zmazać plamy schizmy"44.

I tu warto postawić sobie pytanie: jaki jest stosunek prawoslawnych do sprawy zjednoczenia chrześcijan w prawdziwej wierze i w jednym Kościele? Otóż, stosunek ten jest różny, najczęściej jednak negatywny. Jedni dowodzą, iż rozbicie wśród chrześcijan nie dotyczy samego Kościoła Chrystusowego, dlatego nie ma więc pilnej potrzeby starać się o zjednoczenie chrześcijan. Inni przyznają potrzebę zjednoczenia chrześcijan, sądzą jednak, iż jest to dzielo ponad ludzkie siły i jedynie Opatrzność Boża przy końcu świata dokona tego zjednoczenia. Pozostali wreszcie nie tylko przyznają potrzebę zjednoczenia chrześcijan, ale staraja się o zjednoczenie oraz podają różne sposoby realizowania tego zjednoczenia.

Pierwsi, jak N. Bierdiajew, A. Kartaszew, G. Florowikij, stawiają zbyt śmiałą tezę, iż Kościól jest jeden i niepodzielny, a ta jedność jest samą istotą Kościoła tak, że pojęcie „Kościót" w ścisłym znaczeniu nie dopuszcza liczby mnogiej, chyba w przenośnym i niewłaściwym sensie. Dlatego też wedlug nich nie można mówić o Kościele, że jest podzielony i rozbity, że potrzebuje zjednoczenia, gdyż to nie Kościól, a jedynie chrześcijanie sa podzieleni i rozbici na przeciwstawne sobie grupy. Kościół zawsze jest jeden - w nim żyje Chrystus, w nim udziela się Sakramentów świętych, przez niego wyznawcy Chrystusa otrzymują dary lask dla uświęcenia i zbawienia

43 MPG 62, 87: „Jeżeli poddany króla, nie zdradzając go całkowicie przez odejście do innego, zdziera jednak z niego purpurę i rozrywa na strzępy - czyż taki poddany będzie łagodniej sądzony od tego, który przeszedl do innego króla? Podcbnie bądzie z tym, który nie porzucając Chrystusa, szarpie i rozdziera jego Ciało".

44 MPG $62,85$. 
swoich dusz ${ }^{45}$. Tezę swoją uzasadniają filozoficznie, bez oparcia się o Pismo św., Tradycję lub naukę Ojców Kościoła. Mianowicie, twierdzą oni, iż $w$ Kościele Chrystusıwym należy odróżnič trzy „nawarstwienia faktów”: zewnę'rzne i konkretne przypadłości, pod którymi leży bardziej trwały sys'em dogmatycznych i kanonicznych relacji, a wreszcie pod nim „ta:emne i niedostępne dla rozumu ludzkiego podglebie świata duchowego - Kościół niewidzialny". I właśnie w tym Kościele niewidzialnym nie ma i nigdy nie może być żadnych podziałów. Pcdział nastąpił jedynie $\mathrm{w}$ zewnętrznym Kościele ${ }^{46}$. $\mathrm{Z}$ teorii tej zrodził się wśród prawosławnych interkonfesjonalizm, który glosi, iż chrześcijanin może naieżeć równocześnie do różnych Kościolów i nie musi absolutnie wybierać jednego $z$ nich za swój wlasny Kościół ${ }^{47}$. Wszyscy oni są zdania, że nie ma potrzeby $w$ ogóle starać się o zjednoczenie Kościolów, a jedynie o zjednoczenie chrześzijan, to zn. o wzajemne poznanie i milość pomiędzy chrześcijanami różnych wyznań. Natomiast idea zjednoczenia Kościołów jest wprost fałszywa i nierealna, Kościól bowiem nie może się rozpaść na części, a więc nie może się i zjednoczyć. życie kościelno-religijne nie ma nic w sobie z polityki, czyli że werwnątrz tego życia nie może być czegoś w rodzaju politycznych bloków, układów, ustępstw obustronnych albo różnego rodzaju chwytćw dyplomatycznych. Już sam dźwięk słowa „zjednoczenie Kościołów” wyraża podstęp i obłudę, gdyż zjednoczenie oraz jedność świata chrześcijańskiego nie może być przedmiotem targów i układów Zjednoczenie należy przeprowadzić wewnątrz Kościołów, a nie zaś na powierzchni. Taką jedność można osiągnąć tyiko w sfe-

45 Bjerdjajev N., Zjedyncnnja chrystijan Schodu $i$ Zachodu, inNyva. Lviv 1929, nr 7-8, 276.

Kartašev A., Soiedinenie Cerkvej $v$ sviti istorji, in Christianskoie vozsciedinenie, Paris 1932, 82-83.

Florovskij G., Problcmatika christianskiago vozsoiedinenija, Paris $1933,1-2$.

46 Kartašev A., Puti jedinenia, in Rossija latynstvo, Berlin $1923,147$.

47 Ričnskij A., Problemy ukrainskoji relihijnoji svidomosty, Volodymyr Volynskyj 1933, 267. 
rze mistycznej, w sferze życia duchowego, nie zaś w sierze polityki kościelnej. Wprost przeciwnie, dla pogodzenia i zjednoczenia chrześcijan, należy koniecznie wyeleminować politykę kościelną, gdyż $\mathrm{z}$ dawien dawna byla ona źródlem różnych nieporozumień oraz klćtni wśrćd chrześcijan. Wszelkie układy i targi w sprawie zjednoczenia Kościołów Wschodu i Zachodu prowadzą jedynie do większego jeszcze rozbicia chrześcijan ${ }^{48}$.

Doktryna ta jednak nie znajduje uzasadnienia w Objawieniu ani w nauce Ojców Kościoła, a sprzeciwia się nauce takiego luminarza Kościoła wschodniego, jakim zawsze byl i jest św. Jan Chryzostom. Widzi on w Kcściele Chrystusowym podwójng jedność: wewnętrzną, wynikającą z tego, iż Kościól jest Cia'em Misiycznym Chrystusa i zewnętrzną czyli spoleczną. Również rozróżnia on podwójne oddzieienie się od Kościoła: jedno burzy jedność wewnętrzną, przez zerwanie tych więzów, które łącza wiernych $\mathrm{w}$ jedno Ciało Chrystusowe (miłość i laska); drugie rozrywa jedność zewnętrzną przez wygórowaną ambicję i żądzę panowania, a rozumie przez to wlaściwą schizmę ${ }^{49}$. Dowodzi, że dopśki Kościól partykularny zachっwuje jedność z Kościolem powszechnym, dopóty tworzy w sobie calość i jedność. Przez schizmę zaś traci jedno i drugie - nie ma już w sabie mocy, aby tworzyć calość, czerpał ją bowiem z Kościola powszechnego; nie ma leż jedności w sobie, posiadal ją bowiem jedynie przez uczestniczenie $w$ jedności calego Kościoła powszechnego ${ }^{50}$.

Przedstawiciele drugiej grupy stawiają tezę, iż oprócz jednego prawdziwego Kościola jest jeszcze wiele innych Kościołćw i należy się modlić o nawrócenie zbłąkanych chrześcijan do prawdziwego Kościola, gdyz to polączenie Kościołów nie może się dokonać środkami ludzkimi, lecz tylko ręką Boża, w cudowny sposób i to dopiero $w$ czasach eschatologicznych, kiedy się spełnią już wszystkie proroctwa. Wszelkie zaś ludzkie plany oraz próby zjednoczenia Kościołów, należy oddalać

\footnotetext{
48 Bjerdjajev N., Zjedynennja chrystian..., d. c., 281-2.

49 MPG 62, 85.

50 MPG 61, $23 \mathrm{nn}$.
} 
jako pokusę szatańską ${ }^{51}$. Dlatego to ich zdaniem Kościół wachodni nigdy nie zająl pozytywnego stanowiska $w$ kwestii usunięcia schizmy. Wszystkie dotychczasowe próby unii, nie byly aktem religijnym, lecz ,aktem politycznego wyrachowania", dlatego też nie moga być przypisywane Kościolowi wschodniemu. Unia Florencka z r. 1439 była aktem państwowym, dzięki któremu cesarz bizantyński kupił sobie pomoc Zachodu przeciwko Turkom za cenę, ,wyrzeczenia się czystości wiary". Unia Brzeska z r. 1596 była zaś ,,aktem jawnego gwałtu nad religijnym sumieniem słabszych". Nigdy unia nie była rzeczywistym zjednoczeniem Kościołów, prawie zawsze byla ona wymuszoną i nieszczerą, albo po prostu przejściową formą na drodze do calkowitego łacinizmu ${ }^{52}$. Ci, którzy by zaś pragnęli doprowadzić do prawdziwego zjednoczenia Kościołów, natrafią $w$ swoich wysilkach na caly szereg nieprzezwyciężonych wprost sprzeczności: a) Muszą oni wtedy stanąć ponad Kościołami, a siebie uczynić sędziami nawet swego Kościoła-co jest sprzeczne $z$ wiarą. b) Aby usunąc różnice pomiędzy Kościołami, muszą uznać jeden z Kościolów za nie prawdziwy. A moga tego dokonać jedynie na podstawie dowolnego tiumaczenia Pisma św., niezależnie od nauczania swego Kościola, jeśli zaś w tym jednym wypadku można usunąc swój Kościół jako zbyiecznego pośrednika między Bogiem a scibą, to można to samo uczynic we wszystkich innych wypadkach. W takim razie należałoby dążyć nie do zjednoczenia Kościolów, ale raczej do usunięcia jako niepotrzebnych. c) Każdy Kościół uważa się za niecmylny - aby mogło dojść do zjednoczenia Kościolów, wtedy wierni jednego Kościola musieliby zwątpic w nieomylność swego Kościola, a poddać się pod sąd blądzącego Kościoła. Co jest nielogiczne. d) Do zjedncczenia mogloby dojść przez calkowite poddanie się jednego Kościola drugiemu. Mogłoby dojść do zjednoczenia również przez wzajemne porozumienie co do spornych kwestii. Porozumienie jednak

51 Trubeckoj N. S., Soblasni jedinenija, in Rossija i latynstvo, d. c., 137.

52 Vernadskij G., ,Sojedinenie cerkvej $v$ istoričeskoj dijstvitelnosti, in Rossija i latynstvo, d. c., 115, 119. 
takie w sprawach nauki wiary i dogmatów, mogłoby dojść do skutku jedynie dzięki ustępstwom i kompromisom - co równałoby się niegodnym targom rzeczami świętymi. Takie zjednoczenie byloby owocem grzechu, a więc zgorszeniem i zgubą dla obu Kościołów. Zresztą, w jednym i w drugim wypadku pozostałaby zawsze jakaś mała część duchowienstwa i wiernych przy dawnym Kościele, przez co obok dwóch Kościolów 'powstałby trzeci, co jeszcze bardziej podzieliłoby oraz osłabiło chrześcijaństwo ${ }^{53}$.

Tak więc jest możliwe kompromisowe zjednoçenie Kościolów, ale byloby to dzieło szatana, który stara się uwieść chrześcijan oraz doprowadzić ich do jeszcze większego zła. Prawdziwie zaś zjednoczenie wszystkich chrześcijan w jedną owczarnie pod wladza jednego pasterza, nastapi dopiero $w$ czasach eschatologicznych, nie wiemy jednak jaka ono przybierze formę. Tymczasem zaś każdy chrześcijanin winien być wierny temu Kościołowi, który wydaje mu się być prawdziwym ${ }^{54}$.

Wreszcie przedstawiciele trzeciej grupy teologów wschcdnich, którzy przyznają potrzebę zjednoczenia i troszczą się o nie, potępiają teorie pierwizych dwu grup i odrzucają je jako fałszywe. Fałsz twierdzenia, iż zjednoczenie Kościołów jest niemożliwe oraz niepoirzebne, staje się oczywistym, gdy zwrócimy uwage, iż cba Kościoly, wschodni i zachodni, w swoich nabożeństwach stale modlą się właśnie o zjednoczenie Kaściolów. A przecież modlić się o rzecz nie możliwą oraz nie potrzebną byloby lekkomyślnością bliską bluźnierstwu ${ }^{55}$.

Jednym z najgorliwszych apostolów zjednoczenia Kościolów z tej grupy, byl Włodzimierz Solowiew (1853-1900), Eenialny myśliciel i teolog rosyjski, który ukul znane powszechnje maksymy: „Primum et ante omnia Unitas Ecclesiae instauranda!”, „Ceterum censeo instaurandam esse Ecclesiae

53 Trubeckoj N. S., Soblasni jedinenja..., d. c., 125-136.

54 Trubeckoj N. S., Soblasni jedinenja..., d. c., 139. A. Kartaszew już 40 lat temu sygnalizował zbliżanie się czasów eschatologicz-: nych, w których miałoby dojść do zjednoczenia Kcściłłów.

55 Soloviev VI., Dogmatičeskoje razvitie Cerkvi $v$ svjazi $s$ va. prosom o sojedinenji Cerkvej, Moskva 1886, 1. 
unitatem!"56 On to wzbudzil zainteresowanie teologów wschodnich zjednoczeniem Kościołów przez gloszenie idei religijnej syntezy Wschodu i Zachcdu. Mianowicie, wedlug konceprji Solowiewa, schizma kościelna to nie tylko nieporozumienie hierarchiczne, lecz przede wazystkim jest to zburzenie wewnętrznej równowagi składowych pierwiastków chrystianizmu. Wschód zatrzymal zasadę tradycji dogmatycznej oraz ascezy kontemplacyjnej, natomiast Zachśd zatrzymał pierwiastek autorytetu społecznego w Kościele oraz działalności praktycznej. A ponieważ każdy z Kościolów wciela po rozlamie jedynie jedne pierwiastki i zasady chrześcijańskie, zaniedbując inne, przez co nie ma wzajemnego uzupelniania sie - dlatego chrześcijaństwo nie rozwija się należycie i jest anemiczne. Dopiero zjednoczenie Kościola wschodniego $\mathrm{z}$. zachodnim przywróci harmonię zasad oraz pierwiastków chrześcijańskich, przez co wydatnie przyczyni się do pelnego rozwoju i umocnienia chrześcijaństwa ${ }^{57}$.

I należy przyznać, iż koncepcja Sołowiewa jest konstruk'ywna. Unia bowiem przede wszystkim przywréciłaby Kościolowi wschodniemu dyscyplinę wewnętrzną, bez której życie religijne na Wschodzie słabnie i zamiera. Kościól wschodni posiada wybitnie eschatologiczny charakter. Prawosławie bowiem zawsze bardziej zwracało se do życia wiecznezo, do królestwa niebieskiego, niż do życia ziemskiego. Chrześcijanie wachodni odziedziczyli ducha helleńskiego - mistycyzm kontemplacyjny. Zachód zaś byl zawsze bardziej praktyczny, realny, gdyz przyswoil sobie ducha rzymskiego. Chrześcijanie zachodni byli przekonani, iż Kościół jest powołany do walki ze światem. Natomiast eschatologiczny duch w prawoslawiu paraliżował tworrczą energię, rozbudzal zaś głębzką pobożność i mistycyzm. Te dwa światy nieposiadają więc całej peiności, doskonałości i harmonii - potrzebują wzajemnego dopełnienia przez zjednoczenie obu Kos̉ciolów.

56 Włodzimierz Sołowiew - syn wybitneg, historyka rosyjskieg, Sergius a Solowiewa. W r. 1896 złożył formalne wyznanie wiary rzymskokatolickiej. Swe poglądy unicnisiyczne wyłożył szczególnie w dziełe: La Russie et l'Eglise Universelle.

57 Por. Urban J., Katolicyzm i prawosławie, Kraków 191244 
Spośród nowszych teologów prawosławnych: Piotr Czadajew, prof. Suszkow, prof. Swietlow, S. Troickyj i prof. Bołotow byii rćwnież gorącymi zwolennikami zjednoczenia Kościolów ${ }^{58}$. Podobnie jak obecny patriarcha Konstantynopola, Athenagoras $I_{\text {s }}$ który odnosi się przyjaźnie do Kościola katolickiego ${ }^{59}$, również patriarcha Joachim III przed pierwszą wo:ną światową był przychylny zjednoczeniu. Glosił on zasadę, iż ten, kto pracuje nad usunięciem rozłamu $\mathrm{w}$ Kościele Chrystusowym, dokonuje dzieła godnego pochwały ${ }^{60}$. Również greccy teologowie popierali i popierają nadal sprawę zjednoczenia Wschodu z Zachodem. Wybitny teolog S. Alewizatos z Aten pisal w r. 1932, iz bez względu na trudności, oddzielony Wschód powinien pragnąć zjednoczenia, powinien wierzyć w zjednoczenie i pracować dla niego. Nawo'ywał Wischód do przyjęcia oraz stosıwania zasady: "In fide unitas, in dubiis libertas, in omnibus caritas"61.

Współcześni nam teologowie prawoslawni, prof. G. Florowskij oraz A. Schmemann'62, pisząc na temat zapowiedzianego Soboru, wzywają oddziєlony Wschśd, aby zrewidowal swoje

58 Por. Cerkovni Vjedomosti, Pèersburg 1908, nr 8, 399.

$\mathrm{Buk}$ owski A., Katolicka nauka wiary w przedstawieniu rosyjskich prawostawnych podręczników teologji, in Miesięcznił Kościelny, Poznań 1914, 28-29.

Brinktrine J., Das ökumenische Konzil und die Orihodoxen, in Theologie und Glaube, Paderborn 1959, Heft 4, 244-245.

59 Patriarcha Athenagcras I juz w pierwszej tronowej mowie prze-słal pozdrowienia Stolicy Apostolskiej, zaś w r. 1951, 1953 nader serdecznie przyjął na audiencji delegat'sw Fiusa XII. Por. Das ökumenische Patriarchat von Konstantinopol, in Una Sancta, 1959, Heft 3, 206. - Latem zaś $1959 \mathrm{rcku}$, wyrazil się Athenagoras I do koreşondenta $K$. Bindera $z$ Wiednia: „Pan jest młody, Pan doczeka się jeszcze unii". Por. B in der K., Die byzantinische Kirche..., d. c., 22. Po K :nferenc.i ogólnoprawosławnej (24.IX.1961) zamierza złożyć wizytę Janowi XXII.

60 Pcr. Slip y j J., Unijni zmahannja..., d. c., 129.

61 Alevizatos S., Kak na dili osučšstvit ssiedinenie Cerkvej, in Chiristianskoje vozsojedinenie, Paris 1932, 139-140.

62 G e org Flor ow skij ur. w r. 1893 w Odessie, studiuje w Odessie, $w$ Pradze, następnie w̧świçcony w Paryżu. Tu też zcstaje profesorem w Instytucie Prawosławnym, cd 1918 r. w New Yorku w Seminariun św. Włodzimierza, zaś od $1956 \mathrm{w}$ Harvard. Jest to dzis̃ najwybitniejszy teolog Kcścioła prawısławnego. 
stanowisko względem Kościoła katoliskiego i przygotował się należycie do Soboru. Okazują zadowolenie, iż na przyszlym Soborze Kościół katolicki skoncentruje się głównie na wyjasnieniu nauki o Kościele i hierarchii (co zostało niewyczerpane na I. Soborze Watykańskim), gdyż to będzie miało doniosłe znaczenie dia sprawy zjednoczenia Kościołów. Równocześnie boleją nad tym, iż według dotychczasowych oświadczeń Stolicy Apostolskiej, prawdopodobnie biskupi prawoslawni nie będa formalnie zaproszeni na obrady Soboru, a jedynie będą mogli wysłać tam cíbserwatorów. Mimo wszystko są nastrojeni optymistycznie i zalecają swym wspólwyznawcom ,nadzieję, modlitwe i pracę", celem osiągnięcia rychłego zjednoczenia ${ }^{63}$,

„My nie jesteśmy przeciwni prawdziwemu zjednoczeniu Košciołów - tak zwykle odpowiadają wschodni chrześcijanie na apel Kościola katolickiego do obustronnego porozumienia nie uznajemy tylko takiego zjednoczenia, w którym żąda się od nas, abyśmy zdradzili naszą prawosławną wiarę"64. Wschodni chrześcijanie są więc zdania, iż Kościół katolicki odstąpil od pierwotnej nauki wiary, która czysta i nienaruszona zachowała się do dziś jedynie w Kościele wschodnim. Zjednoczenie więc obu Kościolów jest możliwe według nich tylko pod warunkiem, że Kościól katolicki wyrzeknie się nowych dogmatów oraz prawd wiary, wprowadzonych po VII-ym Soborze Powszechnym i powróci do stanu, w jakim znajdowały się oba. Kościoly przed rozdziałem ${ }^{65}$. Na szczęście coraz częściej w na-

63 Florovskij G., Das bevorstehende Konzil der römischen Kirche, in Una Sancta 1959, Heft 3, 172-175.

Schmemann Alex., Rom, das ökumenische Konzil und die orthodoxe Kirche, in Una Sancta 1959, Heft 4, 283-286.

64. Tabinskyj P., Odna vira, in Nyva 1934, 16.

65. Tezę tę ogłosili urzędowo patriarchowie wschodni w ,Liście okólnym" z 6.V.1848 r. jako odpowiedzi na apel do zjednoczenia Papieża Piusa IX, zawarty $w$ encylklice "In Summa Petri” $z$ r. 1847. Por. MI a n s i, t. 90,377 .

To samo cświadczył, w "Liście okólnym' z r. 1895 Anthymos V, patriarcha Konstantynopola wraz ze swoimi metropolitami w odpowiedzi̊ na encyklikę Leona XIII z r. 1894 ,Praeclara gratulationis". 
szych czasach dają się słyszeć głosy hierarchów oraz teologów wschodnich, którzy opowiadają się za przyjęciem dogmatów katolickich, jeśli na wspólnym soborze zostaną one należycie uzasadnione. Oto wypowiedź patriarchy Konstantynopola, Focjusza II († 1935): „Gdyby papież na podstawie swego pierwszeństwa zwołał sobór, to dla nas nie byloby żadnego sensu nie wziąć w nim udziału, ale tylko pod tym warunkiem, ze rzymski arcybiskup przedłożyłby soborowi do rozpatrzenia i zatwierdzenia to wszystko, co Kościół rzymski wprowadził u siebie jako dogmaty, ad czasu rozłamu aż do dnia dzisiejszego. Gdyby sobór powszechny przyjął wprowadzone przez Kościół rzymski inowacje, my przyjęlibyśmy je także bez zastrzeżeń"66. Podobnie wyraża się prof. A. Kartaszew († 1960), a nawet przyznaje, iż Kościół wschodni nie jest przekonany o posiadaniu ostatecznej pełni prawdy, dlatego przyjmie nowe prawdy katolickie, jeśli one będą na wspólnym soborze dowiedzione ${ }^{67}$.

Teza, propagowana wśród prawosławnych, jakoby Kościól katolicki z biegiem wieków odstąpił od pierwotnej wiary, która zaś czysta i nienaruszona zachowała się jedynie w Kościele prawosławnym, jest fałszywa i nie wytrzymuje krytyki. Jeśli bowiem uważnie oraz obiektywnie przestudiujemy naukę obu Kościołów na podstawie Źródel Objawienia, pism Ojców Kościoła i ksiąg liturgicznych, przekonamy się niezbicie, że właściwie istnieje zgodność dogmatów i prawd wiary, z tym, że Kościół katolicki ogłosił niektóre nowe dogmaty wiary. Poza tym spotykamy jeszcze jedynie różnice w sposobie określania tajemnic wiary (Duch Sw. pochodzi od Ojca i Syna - od Ojca przez Syna) oraz w opiniach teologicznych obu Kościołów - co jest sprawą drugorzędną ${ }^{68}$. Jeśli zaś prawosławni dopa-

66 Messager d'Athenes, Ateny 1932, 76.

$67 \mathrm{~K}$ a r t a šev A., Na putjach k'vsjelenskomu soboru, Paris 1932, 28: „Rimskaja Cerkov... realnaja katoličeskaja cerkov, imivsaja kak takovaja pravo dilat' novovvedenija i formulirovat učenija. $\mathrm{Na}$ uslovijach katoličeskaho ravnopravija pravoslavnaja cerkov pojdet $s$ nej na vselenskoje soborovanije i prijmet kak obscecerkovnoje priobritenie, vsi jeja dostiženije za period razdilnoj žizni, jesli soborno budet dokazana Vostočku ich cerkownaja pravota. Vostok ne sčitajet svoju cerkovnuju žizn vseisčerpivajuščej polnotoj..."

Prawo Kanoniczne -20 
trują się większych różnic we wierze oraz posądzają Kościół katolicki o odchylenia od pierwotnej wiary, to wynika to głównie stąd, iż prywatne opinie teologów przyjmują za oficjalne prawdy wiary swego Kościola. Oto wybitny kanonista rosyjski, N. Suworow, nazywał teologię prawosławną mięszaniną sprzecznych ze sobą prawd i zalecal ostrożność $w$ stosunku do wypowiedzi teologów oraz pisarzy prawosławnych, gdyż jako prawdę „ortodoksji" podają niekiedy oczywisty absurd ${ }^{63}$. Również prof. M. Głubkowskij potwierdzil opinię Suworowa, dowodząc, iż prawosławie nie posiada ustalonych i usankcjonowanych formuł ani ksiąg symbolicznych, które wyrażałyby jego odrębność wyznaniową ${ }^{70}$. Podobnie F. Melnikow, wybitny teolog starowierców rosyjskich, zarzuca Kościołowi prawosławnemu, iż brak mu jednolitej i ustalonej nauki o Kościele, - Chrystusie Panu, o Matce Bożej czy choćby o jednym Sakramencie św. Cała teologia prawosławna, zdaniem Melnikowa, jest zbiorem najrozmaitszych sprzeczności, przeciwieństw, błędów oraz herezji. Melnikow tezę swoją uzasadnia licznymi przykładami. Na przykład, jak to Synod moskiewski w r. 1666/67 jednomyślnie zaaprobował dwa traktaty teologiczne, z których jeden nauczał, iż Matka Boża była niepokalanie poczęta, drugi zaś wprost przeciwnie dowodził, że była poczęta $w$ grzechu pierworodnym ${ }^{71}$. Dlatego to A. Turgeniew, dyrektor Departamentu Spraw Duchownych w Petersburgu, gorszył się tym stanem rzeczy, co wyrazil w słowach: „Nie mam zaufania do naszego duchowieństwa, zmienia ono bowiem katechizmy jednocześnie ze zmianuą ministrów i oberprokuratorów"72.

Nic więc dziwnego, iż prof. N. Swietłow, teolog prawosławny, wszystkie rzekome odstępstwa Kościoła katolickiego nazywa po prostu ,pozornymi odstępstwami”. Jedynie prawdziwa.

68 Tabinskyj P., Za zjednannja Sv. Bożych Cerkov, Kremijanec $1933,4$.

69 Suvorov N., Učebnik cerkovnago prawa, Moskva 1908, 197.

70 H I ubovski MI. Prawostavie po jego sus cestvu, in Christianskoe Ctenie, Petersburg 1914, ks. 1, 3, 5, $14 \mathrm{nn}$.

71 M e $1 \mathrm{nikov}$ F., Bluzjuščeie bohoslovie, Moskva 1911, III. Chodzi tu o „Zezl pravlenia Simeona Polockago" i „Skryžal”. 
oraz istotną różnicę widzi $\mathrm{w}$ nauce katolickiej o papieżu -o jego prymacie i nieomylności. Ale i w tym wypadku prof. Swietłow nie zarzuca Kościolowi katolickiemu formalnej herezji, gdyz jak to sam pisze: ,nauka ta $z$ istoty swojej nie należy do kwestii teoretyczno-dogmatycznych, lecz jest blędem $w$ praktycznym zakresie kościelnej organizacji" i nie została potępiona przez żaden sobór powszechny ${ }^{73}$. A przecież W rzeczywistości i to poważne, nawet według prof. Swietlowa, odstępstwo, jest jedynie pozornym odstępstwem. W najdawniejszych bowiem katalogach błędów łacińskich, począwszy od momentu rozłamu aż do $\mathrm{w}$. XIV sprawa prymatu biskupa Rzymu nie była zupelnie notowana, a z teologów wschodnich do w. XVII ani jeden nie uważał jej za przyczynę nieporozumień między Wschodem i Zachodem ${ }^{74}$. Dopiero prawdopodobnie Maksym Peloponeski pierwszy wyraził pogląd (w r. 1620), iż zwierzchnia władza biskupów Rzymu była przyczyną rozla$\mathrm{mu} \mathrm{w}$ Kościele ${ }^{75}$. A jest to tym bardziej zastanawiające, gdyż papieże w stosunkach ze Wschodem zawsze podkreślali hierarchiczne pierwszeństwo swej Stolicy, jako wypływające z Bożego ustanowienia oraz żądali honorowania tegoż przywileju. Natomiast teologowie wschodni, przeciwnicy schizmy, jawnie obwiniali patriarchów Konstantynopola o zamach na przywlleje biskupa $\mathrm{Rzymu}^{76}$. Aż do wieku XV polemiści greccy zasadniczo przyznawali prawo Stolicy Apostolskiej do zwierzchności nad całym Kościołem. Jeśli zaś czasowo nie chcieli uznać biskupów Rzymu za swoich zwierzchników, to tylko ze względu na ich rzekome ,odstępstwa" od prawdziwej wiary. Przyrzekali zaś poddać się ich zwierzchnictwu, jeżeli tylko powrócą do dawnej wiary ${ }^{77}$.

$\mathrm{Na}$ podstawie powyższych wywodów można postawić tezę, iż oprócz dogmatów maryjnych oraz dogmatu o nieomylności

73. Svietlov N., Christijanskoje vierovčenie, d. c., 193--8.

74 Jugi e IV., Theologia dogmatica christianorum orientalium $a b$ Ecclesia catholica dissidentium, Parisiis 1926, t. 1, 380, 502.

75 Tabinskyj P., Relihijni pytannja $v$ cerkovnomu rozkoli $\mathrm{XI}$ $v i k u$, in Nyva, Lviv 1935, $\mathrm{nr} 1,8$.

76 MG., t. $149, \mathrm{k} 684-685$.

77 Tabińsky j P., Relihijni pytannja.., d. c., 9. 
papieża, które to dogmaty zostaly ogłoszone w oparciu o wpsólne obu Kościołom źródła Objawienia oraz naukę Ojców Kościoła, prawdziwe różnice między Kościołem katolickim i prawosławnym istnieją jedynie $\mathrm{w}$ obrządkach, zwyczajach religijnych oraz w opiniach i poglądach teologów, których absolutnie nie należy stawiać na równi $z$ oficjalną nauką wiary. Czyli że zjednoczenie Kościołów nie wymaga ustępstw we wierze, ale głębszego zrozumienia tej wiary. Toteż zjednoczenie w swojej istocie nie tyle jest sprawą dogmatyczną, ile kanoniczno-dyscyplinarną. $\mathrm{Na}$ tych właśnie przesłankach oparte są wszystkie projekty unijne Stolicy Apostolskiej.

Tęzę tę zdaje się potwierdzać również Kościół prawosławny w praktyce. Oto jeszcze na początku wieku XIII biskupi bułgarscy, Dymitr Chomatyn i Jan Kytrski, nauczali, iż wschodni chrześcijanie mogą uczęszczać na nabożeństwa katolickie78. W Rosji znowu za Katarzyny II (1762-1796) oraz Mikołaja I (1825-1855) przyjmowanie unitów na prawosławie odbywało się bez jakichkolwiek obrzędów kościelnych i formalności. Wystarczyło, jeśli parafia unicka złożyła na piśmie oświadczenie, iż pragnie przyłączyć się do Kościoła prawosławnego, a wtedy oprócz opuszczenia $\mathrm{w}$ nabożeństwach imion papieża i biskupa katolickiego oraz Filioque, wszystko inne zostało bez zmian ${ }^{79}$. Kiedy zaś w r. 1841 Swięty Synod przy sprawdzeniu sprawozdań diecezjalnych, natknął się na indywidualne przyjęcie na prawosławie trzech unitćw, nie omieszkał natychmiast pismem z 24.V.1841 r. przestrzec biskupów diecezjalnych, iż zgodnie z uchwałą Swiętego Synodu, ponieważ Kościól unicki został w całości przyjęty, tym samym wszyscy unici zostali wcieleni do prawosławia, dlatego pojedyńcze przyjęcia nie powinny mieć miejsca, ale wszystkich unitów należy bez przeszkód do-puszczać do Sakramentów świętych oraz innych obrzędów religijnych ${ }^{80}$. Swiadczy to o tym, że Kościół rosyjski nie dopatrywał się żadnych różnic we wierze unitów, a przejśście z jed-

78 MG., t. 119, k 951-962.

79 Tabinskyj P., Odna vira..., d. c., 19.

80 Rukovodstvennie dlja Pravoslavnago Duchovenstva ukazy Sviat. Pravit. Sinoda 1721-1872, Moskva 1872, 350. 
nego Kościoła do drugiego było jedynie zmianą jurysdykcji kościelnej, nie zaś wiary. Dlatego też nie żądano tu formalności, przypisanych przy przyjmowaniu inowierców, jak: publicznego wyrzeczenia się błędów i potępienia ich, wyznania wiary, spowiedzi oraz odczytania specjalnej modlitwy. Swięty Synod z całą pewnością żądałby dopełnienia tych formalności, gdyby uważał unitów za odstępców od ortodoksyjnej wiary, a Synod wprost przeciwnie zabronil żądać tych formalności. I nie można tego uważać za celowe ułatwianie powrotu do prawosławia, dla religijnej propagandy, gdyż w obradach Synodu brał udział wybitny teolog, metropolita Filaret Moskiewski, znany ogólnie z rygorystycznych poglądów na sprawy kościelne.

W rzeczywistości więc, aby odnowić jedność kościelną pomiędzy Wschodem i Zachodem, żaden $z$ Kościołów nie potrzebuje pozbywać się niczego ze swego skarbca wiary, gdyż w skarbcach tych przechowuje się niezmiennie jedna i ta sama wiara. Tylko że Kościół katolicki, słusznie sądząc, że jeśli w pierwszym tysiącleciu chrześcijaństwa dokonywał się $z$ pożytkiem rozwój dogmatów, polegający na autentycznym wyjaśnieniu przez Kościół prawd objawionych - a żaden sobór powszechny nie zabronil autentycznie wyjaśniać prawd wiary w późniejszych czasach, ani nie orzekł, iż rozwój dogmatów zakończył się z siódmym Soborem Powszechnym - to ten rozwój dogmatów może i powinien mieć miejsce również i w czasach późniejszych oraz dzisiejszych. I dziś bowiem czuwa nad Kościołem tenże Duch Sw., który opiekował się nim w pierwszym tysiącleciu. Dziś również obowiązkiem Kościoła jest wyjaśniać, tłumaczyć oraz uprzystępniać ludziom prawdy objawione $^{81}$. Na tej właśnie podstawie Kościół katolicki ogłosił niektóre dogmaty już po rozłamie w Kościele Chrystusowym

81 Rozwój dogmatów w Kościele katolickim polega na odszukiwaniu i określaniu tych prawd objawionych, które tylko niewyraźnie zostały objawione i wskutek tego niewyraźnie oraz niejasno w swoim czasie wierzyli w nie chrześcijanie.

Por. Dąbrowski R., Rozwój dogmatów wediug prawosławnych teologów rosyjskich, Wlocławek 1932, $8 \mathrm{nn}$. 
i podał je do wierzenia. Ogłoszenie jednak tych dogmatów nie należy w żadnym wypadku rozumieć jako podanie do wierzenia nowych prawd, nie znajdujących się w źródłach Objawienia, ale jako autentyczne wyjaśnienie przez Kościól prawd tylko niewyraźnie podanych $\mathrm{w}$ tychże źródłach Objawienia. Aby się o tym przekonać, wystarczy zapoznać się z niektórymi orzeczeniami Kościoła katolickiego w tej sprawie. I tak I Sobór Watykański orzekł, iż: „Wiarą boską i katolicką należy wierzyć tylko w to wszystko, co się znajduje w Słowie Bożym pisanym lub ustnie przekazanym ${ }^{82}$. Również tenże Sobór orzekł, iż: „Nie w tym celu obiecany jest następcom św. Piotra Duch Sw., aby dzięki Jego objawieniom ogłaszali nową naukę, lecz aby dzięki Jego pomocy przekazane im przez Apostołów Objawienie, czyli depozyt wiary, święcie strzegli oraz autentycznie wykładali"83. Wreszcie Pius IX. W Syllabusie uzasadnił też cel ogłaszania nowych dogmatów tymi słowami: „Objawienie Boże jest niedoskonałe (w wyrazie), dlatego też podlega ciągłemu i nieskończonemu postępowi, który by postępowi ludzkiego umysłu odpowiadał"84. Niesłusznie więc teologowie wschodni oskarżają Kościół katolicki o skażenie pierwotnej wiary przez ogloszenie nowych dogmatów i wprowadzenie dodatków, które nieznane były $w$ starożytności chrześcijańskiej.

Tak więc dziś, kiedy to ,...człowiek posłany od Boga, któremu było imię Jan"85, wskazał chrześcijanom drogę ewangelicznej miłości, wzajemnej życzliwości i zrozumienia, kiedy już wiara nie stoi przeciwko wierze, a Kościół przeciwko Kościołowi, trzeba nam starać się przedstawić całą prawdę o katolicyźmie i prawosławiu, by prawosławni poznali swoje prawosławie i przekonali się, że ONO jest KATOLICYZMEM - a wtedy w nie długim czasie doczekamy się upragnionego ZJEDNOCZENIA obu Kościołów. -

$\mathrm{VI} / 61$

82 Por. Denzing er-B a n n w art, Encheridion symbolorum, Fryburg 1928, nr 1792.

83 Tamże, nr 1836.

84 Tamże, nr 1705.

85 Jan, $1,6$. 